\title{
Induced Systemic Resistance Against Fusarium Wilt of Sesame by some Chemical Inducers.
}

\author{
Khalifa, M.M.A.; Ibrahim, M.M.A. and Abd-El-Baky,
} A.A.

\author{
Plant Pathology Research Institute, Agricultural Research
}

Center, 12619, Giza, Egypt.

Tncidence of Fusarium wilt disease of sesame caused by Fusarium Lxysporum f.sp. sesami was successfully controlled under greenhouse and field conditions through enhancing systemic resistance by soaking sesame seeds in concentrations of chemical inducers. Most of the tested treatments were effective in controlling disease under greenhouse conditions. Salicylic acid (2 and $4 \mathrm{mM})$, Bion (4mM), $\mathrm{CoSO}_{4}(1$ and 2ppm) and IBA (100 and $200 \mathrm{ppm})$ were the most effective treatments for controlling the disease because they maximized the percentage of healthy plants compared with the untreated controls. Under field conditions, most of the treatments were also effective in controlling the disease and increasing seed yield. Salicylic acid (2 and $4 \mathrm{mM})$, Bion $(4 \mathrm{mM}), \mathrm{CoSO}_{4}(1$ and $2 \mathrm{ppm})$ and IBA $(200 \mathrm{ppm})$ were the most effective treatments in controlling disease while, salicylic acid $(2 \mathrm{mM})$, Bion $(4 \mathrm{mM}), \mathrm{CoSO}_{4}(2 \mathrm{ppm})$ and IBA (200 ppm) were the most effective treatments in increasing seed yield. Relationship between induced systemic resistance and some biochemical changes like increases in activity of oxidative enzymes (peroxidase and polyphenoloxidase), phenolic compounds, sugars and total free amino acids was observed in root tissues of healthy sesame plants that grown from treated sesame seeds compared with those grown from untreated seeds. Cobalt sulphate at $2 \mathrm{ppm}$, salicylic acid at $2 \mathrm{mM}$ and IBA at $200 \mathrm{ppm}$ were the most effective treatments for stimulating these defense mechanisms with few exceptions.

Keywords: Sesame, Sesamum indicum L. Biochemical changes, seed yield; Fusarium oxysporum f. sp. sesami; wilt, induced systemic resistance.

Sesame (Sesamum indicum L.) is one of the most important oil seed crops in Egypt. It is attacked by several widespread soil borne pathogens which may cause seed decay, damping-off, charcoal rot, root-rot and wilt diseases. (Abdou et al., 2001 and Khalifa 2003). Fusarium wilt disease, caused by Fusarium oxysporum f. sp. sesami (Zaprometoff) Castallani, is considered as one of the major destructive pathogens on sesame especially in Upper Egypt. (Zahra, 1990; Abdou et al., 2001 and Ahmed et. al, 2010) The disease causes quantitative and qualitative yield losses and increases soil infestation with the causal pathogen (Ziedan, 1993 and Khalifa 1997).

Induced systemic resistance (ISR) can be defined as the process of active resistance dependent on the host plants physical or chemical barriers activated by 
biotic or abiotic agents, it sensitizes the plant to respond rapidly after infection by accumulation of phytoalexin, phenols, PR-proteins and activation of lignification and many enzymes such as peroxidase, polyphenoloxidase, catalase, and chitinase (Walters et al., 2007 and Mahmoud, et, al. 2009). Induced systemic resistance is characterized by many advantages. It is non-specific, systemic, durable, safe for human and environment and has positive effects on plant growth and yield (Kuc, 1982 and Bailey and Deverall 1983), all these characteristics are important for modern disease management strategies (Lawton et al., 1993). Some compounds, e.g., salicylic acid (SA); mono and di-potassium phosphate $\left(\mathrm{KH}_{2} \mathrm{PO}_{4} \& \mathrm{~K}_{2} \mathrm{HPO}_{4}\right)$, Benzothiadiazole (Bion), Indole butyric acid (IBA) and cobalt (Co) have been shown to induce resistance in plants (Mahmoud, et, al. 2006, Khalifa et al., 2007 and Mahmoud, et, al. 2009). Several investigators studied the effectiveness of these chemical inducers on Fusarium wilt disease caused by Fusarium oxysporum f. sp. Sesami (Shalaby 1997 and Abdou et al., 2001).

The aim of this investigation was to study the effect of some chemical inducers on Fusarium wilt disease of sesame and identify some of biochemical changes which may associate with induced resistance by these chemicals.

\section{Materials and Methods}

\section{Greenhouse experiment:}

\section{1- Effect of some chemical inducers on the incidence of sesame Fusarium wilt disease:}

The effects of four chemical inducers at 3 concentrations were evaluated as seed soaking treatments for induction of disease resistance against Fusarium wilt disease. The chemical inducers tested were salicylic acid (SA), Bion (Benzothiadiazole), Cobalt sulphate $\left(\mathrm{CoSO}_{4}\right)$ and indole butyric acid (IBA). The concentrations used were: 2, 4 and 8mM for SA, and Bion and 1, 2 and 4ppm for $\mathrm{CoSO}_{4}$ and 100, 200 and 400ppm for IBA. Seeds soaked in sterilized water were planted as control. On the other hand, sesame seeds (Giza 32 variety obtained from Oil Crops Research Section, Field Crops Res. Institute, Agric. Res. Center Giza, Egypt) were soaked for 2.5 hrs in each inducer concentration, then left to air dry for $24 \mathrm{hrs}$ before planting. The treated and non-treated seeds were planted in pots containing soil infested with inocula $(2 \% \mathrm{w} / \mathrm{w})$ of Fusarium oxysporum f. sp. sesami (previously isolated from diseased sesame plants and confirmed their pathogenic capabilities by Khalifa, $1997)$ at the rate of 10 seeds/pot $(25 \mathrm{~cm}$ in diameter). Three replicates were used for each particular treatment. Disease assessment was performed $15 \& 45$ days after planting for pre-\& post-emergence damping-off, respectively. Percentages of wilted and healthy plants were estimated at harvest ( 90 days after sowing).

\subsection{Specific biochemical changes associated with chemical inducers treatments:}

A study was conducted to identify some biochemical changes that associated with induced resistance by various chemical inducer treatments. Activity of oxidative enzymes, Peroxidase (PO) and Polyphenoloxidase (PPO), as well as phenolic compounds (total, free and conjugated phenols); sugars content (total, reducing and non reducing) and total free amino acids were determined in the 15day-old roots of treated and untreated healthy sesame plants. Samples were taken 15 Egypt. J. Phytopathol., Vol. 39, No. 1 (2011) 
days after planting and were extracted according to Goldschmidt et. al. (1968). Also, the procedures suggested by Allam and Hollis (1972) and Matta and Dimond (1963) were used for determining peroxidase (PER) and polyphenoloxidase (PPO) enzymes activity, respectively. Free, conjugated and total phenols were determined using the colorimetric method of Folin Denis as described by Snell and Snell (1953). Reducing, total and non-reducing sugars and total free amino acids were determined according to Thomas and Dutcher (1924) and Moore and Stein (1954), respectively. Phenolic compounds, sugars content and total free amino acids were calculated as milligrams equivalent of catechol, glucose and arginine/g fresh weight of sesame roots.

\section{2- Field experiments:}

The field experiments were carried out on the first week of June during the two successive seasons of 2009 and 2010 under field conditions at Qena government. The field soil was naturally heavily infested with Fusarium oxysporum f. sp. sesami the causal pathogen of Fusarium wilt disease. Randomized complete block design with three replicates for each treatment was used. The field plot was $3.0 \times 3.5 \mathrm{~m}^{2}$ $\left(10.5 \mathrm{~m}^{2}=1 / 400\right.$ feddan $)$ in four rows with about $20 \mathrm{~cm}$ distance between sowing holes (20-30 plant/row). The normal agricultural practices and irrigation were used in this experiment.

The aforementioned chemical inducers and concentrations which were evaluated under greenhouse conditions were also, evaluated under field conditions. Surface sterilized sesame seeds were soaked for 2.5 hours in a known concentration of the inducer. The wetted seeds were left to air dry for 24 hours then sown as previously mentioned.

Disease assessment was measured as percentages of mature plants showing Fusarium wilt symptoms 90 days after planting. Seed yield was determined 20 days after harvest.

\section{Statistical analysis:}

The obtained data were statistically analyzed by analysis of variance (ANOVA). Means were separated by Fisher's protected least significant differences (LSD) at $\mathrm{P} \leq 0.05$ level (Gomez and Gomez, 1984).

\section{Results}

\section{1- Greenhouse experiment:}

1.1. Effect of applying chemical compounds at different concentrations as seed treatments on the incidence of Fusarium wilt disease under greenhouse conditions:

Effectiveness of soaking sesame seeds in solution(s) of different concentrations of the tested chemical compounds [salicylic acid (SA), Bion, $\mathrm{CoSO}_{4}$ and IBA] on the incidence of Fusarium wilt disease at different stages [pre- and post-emergence damping-off at seedling stage, wilted plants at mature stage] are shown in Table (1). In general, the percentage of disease incidence (at the different stages) was significantly decreased while, percentage of healthy plants at mature stage was significantly increased by all tested chemical compounds and concentrations in 
comparison with the control (sterilized water). IBA at 200ppm was the superior seed treatment for decreasing pre-emergence damping off $(0.0 \%)$ followed by $\mathrm{CoSO}_{4}$ at $1 \mathrm{ppm}$ and Bion at $4 \mathrm{mM}(3.3 \%)$. Meanwhile, SA at $2 \mathrm{mM}$ and IBA at $100 \mathrm{ppm}$ were the best treatments for minimizing post-emergence damping off $(3.3 \%)$. However, $\mathrm{CoSO}_{4}$ at $2 \mathrm{ppm}$ was the best treatment for decreasing incidence of wilted plants $(0.0 \%)$ followed by $\mathrm{CoSO}_{4} 12 \mathrm{ppm}$ and IBA at 100ppm (3.3\%). On the other hand, IBA at $100 \mathrm{ppm}$ followed by IBA at $200 \mathrm{ppm}$ and $\mathrm{CoSO}_{4}$ at $1 \mathrm{ppm}$ were the best treatments for maximizing healthy plants $(86.7,83.3$ and $83.3 \%$, respectively).

Table (1): Effect of different chemical inducers at three concentrations, as seed soaking treatments, on the incidence of damping-off, and wilt diseases of sesame under greenhouse conditions in artificially infested soil

\begin{tabular}{|c|c|c|c|c|c|}
\hline \multirow{2}{*}{\multicolumn{2}{|c|}{ Treatments }} & \multicolumn{4}{|c|}{ Disease incidence $(\%)$} \\
\hline & & \multicolumn{2}{|c|}{ Seedling stage } & \multicolumn{2}{|c|}{ Mature stage } \\
\hline Chemical Inducers & Conc. & $\begin{array}{c}\text { Pre- } \\
\text { emergence }\end{array}$ & $\begin{array}{c}\text { Post- } \\
\text { emergence }\end{array}$ & $\begin{array}{l}\text { Wilted } \\
\text { plants }\end{array}$ & $\begin{array}{c}\text { Healthy } \\
\text { plants }\end{array}$ \\
\hline \multirow{3}{*}{ Salicylic acid (SA) } & $2 \mathrm{mM}$ & 10.0 & 3.3 & 10.0 & 76.7 \\
\hline & $4 \mathrm{mM}$ & 13.3 & 6.7 & 6.7 & 73.3 \\
\hline & $8 \mathrm{mM}$ & 16.7 & 16.7 & 13.3 & 53.3 \\
\hline \multirow{3}{*}{ Bion } & $2 \mathrm{mM}$ & 6.7 & 16.7 & 10.0 & 66.7 \\
\hline & $4 \mathrm{mM}$ & 3.3 & 10.0 & 16.7 & 70.0 \\
\hline & $8 \mathrm{mM}$ & 13.3 & 16.7 & 20.0 & 50.0 \\
\hline \multirow{3}{*}{$\mathrm{CoSO}_{4}$} & $1 \mathrm{ppm}$ & 3.3 & 10.0 & 3.3 & 83.3 \\
\hline & $2 \mathrm{ppm}$ & 6.7 & 13.3 & 0.0 & 80.0 \\
\hline & 4 ppm & 10.0 & 13.3 & 6.7 & 70.0 \\
\hline \multirow{3}{*}{$\begin{array}{l}\text { Indole butyric acid } \\
\text { (IBA) }\end{array}$} & $100 \mathrm{ppm}$ & 6.7 & 3.3 & 3.3 & 86.7 \\
\hline & $200 \mathrm{ppm}$ & 0.0 & 6.7 & 10.0 & 83.3 \\
\hline & $400 \mathrm{ppm}$ & 10.0 & 13.3 & 6.7 & 70.0 \\
\hline Control & - & 23.3 & 20.0 & 26.7 & 30.0 \\
\hline \multicolumn{2}{|l|}{ L.S.D. at $5 \%$ for } & 8.17 & 7.23 & 10.30 & 13.96 \\
\hline
\end{tabular}

1.2. Effect of applying chemical compounds at different concentrations as seed treatments on stimulation of the natural defense mechanisms in sesame plants:

1.2.1. Effect on activities of the oxidative enzymes:

Data in Table (2) prove that the activities of the oxidative enzymes [peroxidase (PER) and polyphenoloxidase (PPO)], expressed as optical density (OD)/minute/g

Egypt. J. Phytopathol., Vol. 39, No. 1 (2011) 
fresh weight, were significantly increased in sesame roots by using any of the tested chemical inducer concentration as seed treatment.

The peroxidase activity was increased to $0.805-1.316$ while, polyphenoloxidase activity was increased to $0.868-1.430$ comparing with the untreated control which recorded 0.331 and 0.355 for both enzymes, respectively. Among all tested treatments, using IBA at 200ppm recorded the highest increase in PER activity (1.316) followed by SA at $2 \mathrm{mM}$ (1.152), and $\mathrm{CoSO}_{4}$ at $1 \mathrm{ppm}$ (1.148), meanwhile, using Bion at $8 \mathrm{mM}$ recorded the lowest one (0.805). As for PPO activity, similar trend, with few exceptions, was also noticed. In general, applying SA at $2 \mathrm{mM}$ (1.430) followed by $\mathrm{CoSO}_{4}$ at $2 \mathrm{ppm}$ and IBA at $200 \mathrm{ppm}$ recorded the highest increase in PPO activity (1.335 \&1.322, respectively) while, Bion at $8 \mathrm{mM}(0.868)$ recorded the lowest one in this regard.

Table (2): Activity of peroxidase and polyphenoloxidase enzymes in healthy sesame roots as affected by treating sesame seeds with different chemicals inducers at three concentrations.

\begin{tabular}{|l|c|c|c|}
\hline \multicolumn{2}{|c|}{ Treatments } & \multicolumn{2}{c|}{$\begin{array}{c}\text { Enzyme activity as OD/minute/g fresh } \\
\text { weight }\end{array}$} \\
\hline \multirow{3}{*}{ Chemical Inducers } & Conc. & $\begin{array}{c}\text { Peroxidase activity } \\
\text { (PER) }\end{array}$ & $\begin{array}{c}\text { Polyphenoloxidase } \\
\text { activity (PPO) }\end{array}$ \\
\hline \multirow{3}{*}{ Salicylic acid (SA) } & $2 \mathrm{mM}$ & 1.152 & 1.430 \\
\cline { 2 - 4 } & $4 \mathrm{mM}$ & 1.099 & 1.315 \\
\cline { 2 - 4 } & $8 \mathrm{mM}$ & 0.961 & 1.229 \\
\hline \multirow{3}{*}{ Bion } & $2 \mathrm{mM}$ & 0.820 & 0.965 \\
\cline { 2 - 4 } & $4 \mathrm{mM}$ & 1.060 & 0.896 \\
\cline { 2 - 4 } & $8 \mathrm{mM}$ & 0.805 & 0.868 \\
\hline \multirow{3}{*}{ CoSO 4} & $1 \mathrm{ppm}$ & 1.148 & 1.237 \\
\cline { 2 - 4 } & $2 \mathrm{ppm}$ & 1.030 & 1.335 \\
\cline { 2 - 4 } & $4 \mathrm{ppm}$ & 0.986 & 1.260 \\
\hline \multirow{3}{*}{$\begin{array}{l}\text { Indole butyric acid } \\
\text { (IBA) }\end{array}$} & $100 \mathrm{ppm}$ & 1.014 & 1.185 \\
\cline { 2 - 4 } & $200 \mathrm{ppm}$ & 1.316 & 1.124 \\
\hline Control & $400 \mathrm{ppm}$ & 1.083 & 0.355 \\
\hline L.S.D. at 5\% for & - & 0.331 & 0.075 \\
\hline
\end{tabular}

\subsubsection{Effect on phenols content:}

Data in Table (3) show that, all the tested inducing-chemical treatments increased the phenol contents comparing with the untreated control. The obtained results prove that the highest increase in the amounts of phenol contents (free and total) were recorded by using SA at $2 \mathrm{mM}(6.887 \& 5.758 \mathrm{mg})$ and IBA at 200ppm (6.651 \& 5.514mg), respectively, meanwhile, bion at $4 \mathrm{mM}$ recorded the lowest increase $(4.013 \& 3.106 \mathrm{mg})$ in this respect. 
As for conjugated phenols, similar trend (with few exceptions) was also noticed. Using IBA at 200ppm caused the highest increase in the conjugated phenols (1.137 $\mathrm{mg}$ ) while, $\mathrm{CoSO}_{4}$ at $4 \mathrm{ppm}$ caused the lowest increase in this regard $(0.729 \mathrm{mg})$ comparing with the untreated control $(0.540 \mathrm{mg})$.

Table (3): Phenol content (free, conjugated, and total phenols) in healthy sesame roots as affected by treating sesame seeds with different chemicals inducers at three concentrations.

\begin{tabular}{|c|c|c|c|c|}
\hline \multicolumn{2}{|l|}{ Treatments } & \multicolumn{3}{|c|}{ Phenol's content (mg/g fresh weight) } \\
\hline Chemical Inducers & Conc. & Total & Free & Conjugated \\
\hline \multirow{3}{*}{ Salicylic acid (SA) } & $2 \mathrm{mM}$ & 6.887 & 5.758 & 1.129 \\
\hline & $4 \mathrm{mM}$ & 5.960 & 4.946 & 1.014 \\
\hline & $8 \mathrm{mM}$ & 5.738 & 4.681 & 1.057 \\
\hline \multirow{3}{*}{ Bion } & $2 \mathrm{mM}$ & 5.114 & 4.086 & 1.028 \\
\hline & $4 \mathrm{mM}$ & 4.013 & 3.106 & 0.907 \\
\hline & $8 \mathrm{mM}$ & 4.126 & 3.257 & 0.869 \\
\hline \multirow{3}{*}{$\mathrm{CoSO}_{4}$} & $1 \mathrm{ppm}$ & 5.983 & 5.024 & 0.959 \\
\hline & $2 \mathrm{ppm}$ & 5.787 & 4.816 & 0.971 \\
\hline & $4 \mathrm{ppm}$ & 5.492 & 4.763 & 0.729 \\
\hline \multirow{3}{*}{ Indole butyric acid (IBA) } & $100 \mathrm{ppm}$ & 5.730 & 4.765 & 0.965 \\
\hline & $200 \mathrm{ppm}$ & 6.651 & 5.514 & 1.137 \\
\hline & $400 \mathrm{ppm}$ & 5.419 & 4.334 & 1.085 \\
\hline Control & - & 1.563 & 1.023 & 0.540 \\
\hline \multicolumn{2}{|l|}{ L.S.D. at $5 \%$ for } & 0.468 & 0.079 & 0.083 \\
\hline
\end{tabular}

\subsubsection{Effect on sugars content:}

Data presented in Table (4) reveal that, all tested chemical inducers treatments caused significant increase in sugars content (reducing, non-reducing and total sugars) comparing with the untreated control. The obtained results prove that, Bion at $4 \mathrm{mM}$ and IBA at $100 \mathrm{ppm}$ recorded the highest increase in the total and reducing sugars $(2.534 \& 1.930 \mathrm{mg})$ and $(2.511 \& 1.915 \mathrm{mg})$ respectively, meanwhile, Bion at $2 \mathrm{mM}$ recorded the lowest increase in this respect. However, the highest increase in amount of the non-reducing sugars, were produced by SA at $8 \mathrm{mM}(0.822 \mathrm{mg})$ followed by $\mathrm{CoSO}_{4}$ at $4 \& 2 \mathrm{ppm}(0.755 \& 0.745 \mathrm{mg})$ while, IBA at $400 \mathrm{ppm}$ recorded the lowest increase in this respect comparing with the untreated control (0.409 mg).

\subsubsection{Effect on the total free amino acids content:}

Data in Table (5) demonstrate that, the total free amino acids in sesame roots was significantly increased to different extents by all tested chemical inducers treatments comparing with untreated control. Using $\mathrm{CoSO}_{4}$ at $2 \mathrm{ppm}(1.389 \mathrm{mg})$ and SA at $2 \mathrm{mM}(1.342 \mathrm{mg})$ caused the highest increases in amount of total free amino acids, followed by bion at $4 \mathrm{mM}(1.334 \mathrm{mg})$ and IBA at 200ppm $(1.285 \mathrm{mg})$.

Egypt. J. Phytopathol., Vol. 39, No. 1 (2011) 
Table (4): Sugar's content (reducing, non-reducing and total sugars) in healthy sesame roots as affected by treating sesame seeds with different chemicals inducers at three concentrations.

\begin{tabular}{|c|c|c|c|c|}
\hline \multicolumn{2}{|c|}{ Treatments } & \multicolumn{3}{|c|}{ Sugar content (mg/g fresh weight) } \\
\hline Chemical Inducers & Conc. & Total & Reducing & $\begin{array}{l}\text { Non- } \\
\text { reducing }\end{array}$ \\
\hline \multirow{3}{*}{ Salicylic acid (SA) } & $2 \mathrm{mM}$ & 2.342 & 1.767 & 0.575 \\
\hline & $4 \mathrm{mM}$ & 2.216 & 1.659 & 0.557 \\
\hline & $8 \mathrm{mM}$ & 2.204 & 1.382 & 0.822 \\
\hline \multirow{3}{*}{ Bion } & $2 \mathrm{mM}$ & 1.810 & 1.338 & 0.472 \\
\hline & $4 \mathrm{mM}$ & 2.534 & 1.930 & 0.604 \\
\hline & $8 \mathrm{mM}$ & 2.384 & 1.827 & 0.557 \\
\hline \multirow{3}{*}{$\mathrm{CoSO}_{4}$} & $1 \mathrm{ppm}$ & 2.313 & 1.692 & 0.621 \\
\hline & $2 \mathrm{ppm}$ & 2.503 & 1.758 & 0.745 \\
\hline & $4 \mathrm{ppm}$ & 2.463 & 1.708 & 0.755 \\
\hline \multirow{3}{*}{$\begin{array}{l}\text { Indole butyric acid } \\
\text { (IBA) }\end{array}$} & $100 \mathrm{ppm}$ & 2.511 & 1.915 & 0.596 \\
\hline & $200 \mathrm{ppm}$ & 2.304 & 1.794 & 0.510 \\
\hline & $400 \mathrm{ppm}$ & 2.045 & 1.613 & 0.432 \\
\hline Control & - & 1.395 & 0.986 & 0.409 \\
\hline \multicolumn{2}{|l|}{ L.S.D. at $5 \%$ for } & 0.034 & 0.012 & 0.011 \\
\hline
\end{tabular}

\section{Field experiments:}

3.1. Influence of some chemical inducers at certain concentrations on sesame Fusarium wilt disease incidence and seed yield production under field conditions:

The obtained results (Table 6) illustrate that, all chemical inducers treatments significantly decreased incidence of Fusarium wilt disease and increased sesame seed yield production during both seasons 2009 and 2010 in comparison with the untreated control. The obtained results prove that, using $\mathrm{CoSO} 4$ at $2 \& 1 \mathrm{ppm}$ $(16.2 \& 18.2 \%)$, IBA at 200ppm (19.5\%) and SA at $2 \mathrm{mM}(20.5 \%)$ in the first season and CoSO 4 at $2 \& 1 \mathrm{ppm}(11.9 \& 14.7 \%)$, IBA at $200 \mathrm{ppm}(13.6 \%)$ and SA at $4 \mathrm{mM}$ $(14.1 \%)$ in the second season, were the most effective treatments for minimizing Fusarium wilt disease incidence $(\%)$ while, Bion at $8 \mathrm{mM}(27.4 \& 23.4 \%$ in season $2009 \& 2010$, respectively) was the least effective in this respect compared to untreated control (40.5\& $37.7 \%$ in season $2009 \& 2010$, respectively) and other tested treatments. 
Table (5): Total free amino acids in healthy sesame roots as affected by treating sesame seeds with different chemical inducers at three concentrations.

\begin{tabular}{|c|c|c|c|}
\hline \multirow{2}{*}{ Chemical Inducers } & \multicolumn{3}{|c|}{$\begin{array}{c}\text { Total free amino acids } \\
\text { (mg/g fresh weight) } \\
\text { at three concentrations } *\end{array}$} \\
\cline { 2 - 4 } & I & II & III \\
\cline { 2 - 4 } & 1.389 & 1.269 & 1.015 \\
\hline Salicylic acid (SA) & 1.204 & 1.334 & 1.118 \\
\hline Bion & 1.227 & 1.432 & 1.104 \\
\hline CoSO $_{4}$ & 1.199 & 1.285 & 1.215 \\
\hline Indole butyric acid (IBA) & 0.612 & 0.612 & 0.612 \\
\hline Control & \multicolumn{3}{|c}{0.084} \\
\hline L.S.D. at 5\% for
\end{tabular}

* SA and Bion, were used at 2, 4 and 8mM conc., $\mathrm{CoSO}_{4}$ was used at, 1, 2 and 4ppm conc. and IBA was used at 100, 200 and 400ppm conc.

Table (6): Effect of different chemical inducers at three concentrations, as seed soaking treatment on Fusarium wilt disease incidence and seed yield production of sesame under field conditions during 2009 and 2010 growing seasons

\begin{tabular}{|l|c|c|c|c|c|}
\hline \multicolumn{2}{|c|}{ Treatments } & \multicolumn{2}{c|}{ Wilted plants \% } & \multicolumn{2}{c|}{$\begin{array}{c}\text { Seed yield } \\
\text { (kg/feddan) }\end{array}$} \\
\hline Chemical Inducers & Conc. & 2008 & 2009 & 2008 & 2009 \\
\hline \multirow{3}{*}{ Salicylic acid (SA) } & $2 \mathrm{mM}$ & 20.5 & 19.2 & 328.4 & 393.2 \\
\cline { 2 - 6 } & $4 \mathrm{mM}$ & 22.4 & 14.1 & 310.5 & 421.2 \\
\cline { 2 - 6 } & $8 \mathrm{mM}$ & 25.6 & 21.4 & 307.1 & 389.1 \\
\hline \multirow{3}{*}{ Bion } & $2 \mathrm{mM}$ & 26.1 & 22.8 & 278.6 & 289.4 \\
\cline { 2 - 6 } & $4 \mathrm{mM}$ & 24.2 & 19.6 & 294.8 & 323.6 \\
\cline { 2 - 6 } & $8 \mathrm{mM}$ & 27.4 & 23.4 & 230.9 & 276.8 \\
\hline \multirow{3}{*}{ CoSO 4} & $1 \mathrm{ppm}$ & 18.8 & 14.7 & 333.9 & 407.1 \\
\cline { 2 - 6 } & $2 \mathrm{ppm}$ & 16.2 & 11.9 & 352.8 & 433.8 \\
\cline { 2 - 6 } & $4 \mathrm{ppm}$ & 22.1 & 16.8 & 327.6 & 396.2 \\
\hline \multirow{2}{*}{$\begin{array}{l}\text { Indole butyric acid } \\
\text { (IBA) }\end{array}$} & $100 \mathrm{ppm}$ & 23.0 & 17.4 & 272.5 & 322.2 \\
\cline { 2 - 6 } & $200 \mathrm{ppm}$ & 19.5 & 13.6 & 321.2 & 353.7 \\
\cline { 2 - 6 } & $400 \mathrm{ppm}$ & 24.6 & 20.6 & 260.1 & 345.3 \\
\hline Control & - & 40.5 & 37.7 & 137.3 & 169.7 \\
\hline L.S.D. at 5\% for & & 5.16 & 4.46 & 6.59 & 7.19 \\
\hline
\end{tabular}

On the other hand, CoSO4 at $2 \& 1 \mathrm{ppm}$ produced the highest seed yield production in season 2009 (352.8 \& $333.9 \mathrm{~kg} /$ feddan, respectively) followed by SA at $2 \mathrm{mM}$ and $\mathrm{CoSO} 4$ at $4 \mathrm{ppm}$, whereas $\mathrm{CoSO} 4$ at $2 \mathrm{ppm}$ and $\mathrm{SA}$ at $4 \mathrm{mM}$ produced the highest seed yield production in season 2010 (433.8 \& $421.2 \mathrm{~kg} / \mathrm{feddan}$, respectively) meanwhile, Bion used at $8 \mathrm{mM}$ produced the lowest increase in seed yield during both seasons 2009 and 2010 (230.9 and $276.8 \mathrm{~kg} /$ feddan, respectively)

Egypt. J. Phytopathol., Vol. 39, No. 1 (2011) 
comparing with the untreated control which recorded 137.3 and $169.7 \mathrm{~kg} /$ feddan in both seasons, respectively.

\section{Dis c us sion}

Induced systemic resistance (ISR) of plants against pathogens is a widespread phenomenon that has been intensively investigated with respect to the underlying signaling pathways as well as to its potential use in plant protection. Elicited by a local infection, plants respond with a salicylic-dependent signaling cascade that leads to the systemic expression of a broad spectrum and long-lasting disease resistance which is efficient against fungi, bacteria, and viruses (Heil and Bostock, 2002). The results of this study revealed that resistance to sesame Fusarium wilt disease could be induced by chemical treatments. The obtained results indicate that all chemical inducers treatments decreased damping-off (pre-\& post-emergence) and wilted plants and produced the maximum healthy standing plants of sesame than the controls under both greenhouse and field conditions. In greenhouse, applying IBA at 200ppm, $\mathrm{CoSO}_{4}$ at $1 \mathrm{ppm}$ and Bion at $4 \mathrm{mM}$ were the superior seed treatments for decreasing pre-emergence damping-off whereas, SA at $2 \mathrm{mM}$ and IBA at $100 \mathrm{ppm}$ were the best treatments for minimizing post-emergence damping-off while, $\mathrm{CoSO}_{4}$ at $2 \mathrm{ppm}$ followed by $\mathrm{CoSO}_{4}$ at $1 \mathrm{ppm}$ and IBA at $100 \mathrm{ppm}$ were the best superior ones for decreasing incidence of wilted plants. On the other side, IBA at 100ppm followed by IBA at $200 \mathrm{ppm}$ and $\mathrm{CoSO}_{4}$ at $1 \mathrm{ppm}$ were the best treatments for maximizing healthy plants. In the field trials, CoSO4 (2\&1ppm), IBA at 200ppm and SA (2mM) in the first season and CoSO4 (2ppm), IBA (200ppm) and SA $(4 \mathrm{mM})$ in the second season were the most effective for decreasing incidence of Fusarium wilt and increasing healthy plants. These findings are in agreement with these of Shalaby (1997) and Abdou et al. (2001). El-Fiki et al. (2004) stated that, IBA $(100 \mathrm{ppm})$ and SA $(4 \mathrm{mM})$ were the superior treatments as they completely suppressed incidence of charcoal rot and produced the maximum healthy standing plants of sesame. Khalifa et al. (2007) soaked sesame seeds before sowing in certain.

concentrations of some chemicals to stimulate the nature defense mechanisms in sesame plants against charcoal rot disease under greenhouse and field conditions and showed that, applying cobalt sulfate $(2 \mathrm{ppm})$ and salicylic acid $(4 \mathrm{mM})$ followed by Bion (4mM) IBA (100ppm) were the most effective treatments for decreasing charcoal rot incidence. Gado (1997) recorded that soaking watermelon seeds in a low concentration of $\mathrm{CoSO}_{4}$ was effective in inducing resistance to Fusarium wilt disease. The use of chemical compounds as the inducers of systemic resistance may increase the resistance of sesame plants against Fusarium wilt disease without direct fungicidal activity (Métraux,1991). Salicylic acid is recognized as an endogenous signal, mediating in plant defense, against pathogens leading to systemic acquired resistance (SAR). Also, plays a role in the resistance of pathogens by inducing the production of pathogenesis-related proteins (PR). (Vernooij et al. 1994 and Métraux, 2001) and its accumulation is required for the establishment of local and systemic required resistance responses (Dempsey et al. 1999). Many workers explained the role of cobalt in enhancing the induced resistance in plants (Zaky et, al., 2002, Mazen, 2004 Morsy, 2005 and Mahmoud et al. 2009). They stated that, cobalt can 
be activated a new protein, as chitinase and/or other pathogenesis-related proteins and activated many of enzymes, which have a role in disease resistance. Moreover, cobalt is known to promote many processes of plant growth including leaf expansion, stem, and. root elongation (Yu and Yang, 1979 and Atta et al., 1991). Bion, activates various defense responses ranging from hypersensitive cell death (HR) of pathogen-attacked cells up to accumulation of reactive oxygen intermediates (ROI) like $\mathrm{H}_{2} \mathrm{O}_{2}$ and the expression of a number of PR genes, which together might control microbial pathogens (Sauerborn et al., 2001).

On the other hand, CoSO4 at $2 \& 1 \mathrm{ppm}$ produced the highest seed yield production in season 2009 followed by SA at $2 \mathrm{mM}$ and CoSO 4 at $4 \mathrm{ppm}$, whereas $\mathrm{CoSO} 4$ at $2 \mathrm{ppm}$ and $\mathrm{SA}$ at $4 \mathrm{mM}$ produced the highest seed yield production in season 2010. These results agree with the results of Khalifa et al. (2007). Induced systemic resistance has positive effects on plants growth, and yield (Bailey and Deverall, 1983). Prakash et al. (1995) concluded that, sesame seed soaking with hormonal treatments and other inducer chemicals increased percentage of sesame seed germination as well as shoot and root length and vigor index. Sallam, (1997) mentioned that, using IAA and $\mathrm{CoSO}_{4}$ as elicitors increased yield components of wheat.

Relationship between induced resistance and some biochemical changes in plant tissues increased the activity of enzymes, salicylic acid content and accumulation of phenols compounds and has become a model of plant disease resistance. These biochemicals became a marker for induced resistance (Reuveni et al. 1992 and Oostendrop et al. 2001).

In the present work, studying some biochemical changes as markers for the induced systemic resistance indicated that considerable increases in activity of oxidative enzymes (peroxidase and polyphenoloxidase), phenolic compounds, sugars and total free amino acids were observed in root tissues of healthy sesame plants that grown from treated sesame seeds comparing with those grown from untreated seeds. In general, CoSO4 (2\&1ppm), IBA (200\&100ppm) and SA $(2 \& 4 \mathrm{mM})$ were the most effective treatments for stimulating these defense mechanisms in this regard with few exceptions. The obtaained results, in general, agree with those obtained by El-Fiki et al. (2004) and Khalifa et al. (2007). Shalaby and Saeed (2000) investigated the biochemical defense mechanisms which may associate with the induced resistance in sesame plants with flower extract of Helichrusum plants, B. subtilis, amino buteric acid (ABA) and Kcl against wilt disease caused by $F$. oxysporum f.sp. sesami and indicated that, increase in peroxidase, polyphenoloxidase and chitinase enzymes activity; in IAA hormone and in RNA content of sesame plants may be as a biochemical mechanism for induced systemic resistance in sesame plant against wilt disease.

PER and PPO might catalyses the formation of lignin and other oxidative phenols that contribute to formation of defense barriers for reinforcing the cell structure (Avdiushko et al. 1993). Also, phenol compounds play an important role in plant defense since they are essential for the biosynthesis of lignin, which are considered an important structural component of plant cell walls to prevent pathogen

Egypt. J. Phytopathol., Vol. 39, No. 1 (2011) 
ingress. Phenols accumulate near infected tissues thus inhibit the development of pathogen in the tissue (El-Modafar and El-Boustani, 2005).

Peroxidases have several functions, which could influence the resistance of a plant such as lignin production, phenylalanine ammonialyase activity, and phenol accumulation (Edreva, 1989). In the present work, IBA at $200 \mathrm{ppm}, \mathrm{SA}$ at $2 \mathrm{mM}$ and $\mathrm{CoSO}_{4}$ at $1 \& 2 \mathrm{ppm}$ recorded the highest PER and PPO activity. Some chemical inducers such as salicylic acid played an important role in generation of the oxidative burst in incompatible interactions by inducing a rapid transient generation of $\mathrm{O}_{2}{ }^{-}$which is responsible of peroxidase activity regulation (Rao et 1997).

This study provides further evidence that, soaking sesame seeds with chemical inducers increased phenolic compounds, sugars and total free amino acids in healthy sesame roots. Phenolic compounds have an important role in protecting sesame tissues from invasion and colonization by $F$. oxysporum f.sp. sesami. This enhanced phenol level might help to inhibit the development of the $F$. oxysporum f.sp. sesami infection. Phenolic compounds have been associated with defense mechanisms because of their general accumulation near infected tissues and those phenols upon oxidation become highly reactive and are toxic to pathogens and pathogenic enzymes, thus inhibit the development of pathogen in the tissue (El-Modafar and ElBoustani, 2005).

Rao et al. (1992) revealed that, the mean values of reducing sugars and nonreducing sugars were higher in resistant plants of sorghum to charcoal rot disease caused by M. phaseolina. Hussien, (1999) found that, the highest concentration of total, reducing and non reducing sugars were recorded in healthy leaves of barley cv. Giza 123 treated with chemical inducer cobalt than in the untreated control.

Abd-El-Megid et al. (2004) found that, amount of amino acids was higher in healthy tissues of antioxidant-treated onion bulb and garlic cloves than infected ones. Also, Youssef and Youssef (1971) reported that, free amino acids content was increased in resistant plants of cotton against $F$. oxysporum infection and suggested that amino acids might play a role in the defense mechanism in plants against root pathogens. Amino acid biosynthetic pathways in plants lead to the production of various secondary products that function as growth regulators, in defense against pathogens and other environmental stresses (Kutchan, 1995).

\section{Ref e r e n e e s}

Abd-El-Megid, M.S.; Abd-El-Momen, S.M. and Ibrahim, N.A. 2004. Effect of some antioxidants on white rot in onion and garlic and their yield. Egyptian J. of Agric.Res.,82(3): 1059-1073.

Abdou, E.; Abd-Alla, H.M. and Galal, A.A. 2001. Survey of sesame root rot/wilt disease in Minia and their possible control by ascorbic and salicylic acids. Assiut J. Agric. Sci., l (23):135-152.

Ahmed, H.A.M.; Abdel-Razik, A.A.; Hassan, M.H.A. and Khaled, S.A. 2010. Management of charcoal rot of sesame by seed soaking in medicinal plants extracts and hot water. Plant Pathol. J., 26 (4): 372-379. 
Allam, A.I. and Hollis, S.P. 1972. Sulfide inhibition of oxidase in rice root. Phytopathology, 62: 634-639.

Atta, U.A.; Shehata, N.G. and Kobbia, T.U. 1991. Effect of cobalt on tomato plant growth and mineral content. Ann. Agric. Sci. Ain Shams Univ., Cairo., Egypt., 36: 617-624.

Avdiushko, S.A.; Ye, X.S. and Kuc, J. 1993. Detection of several enzmetic activities in leaf prints of cucumber plants. Physiological and Molecular Plant Pathology, 42: 441-454.

Bailey, J.A. and Deverall, B.J. 1983. The dynamics of host defense. Induced systemic resistance in plants to diseases caused by fungi and bacteria, p. 191221. Acad. Press. Sydney, New York.

Dempsey, D.M.A.; Shah, J. and Klessig, D.F. 1999. Salicylic acid and disease resistance in plants. Crit. Rev. Plant Sci., 18: 547-575.

Edreva, A. 1989. Host-parasite relations: Biochemistry. Pages 105-140 in: Blue Mold of Tobacco. W. E. Mckeen, ed. The Amer. Phytopathol. Soc., St. Paul, MN.

El-Fiki, A.I.I.; Mohamed, F.G.; El-Deeb, A.A. and Khalifa, M.M.A. 2004. Some applicable methods for controlling sesame charcoal rot disease (Macrophomina phaseolina) under greenhouse conditions. Egypt. J. Phytopathol., 32(1-2): 87101.

El-Modafar, C. and El-Boustani, E.S. 2005. The role of phenols in plant defense mechanisms. Biopesticdes of Plant origin, 157-171 (Book chapter).

Gado, E.A. 1997. Studies on the mechanisms of induced resistance to Fusarium wilt of watermelon. M.Sc. Thesis., Fac. Agric., Ain Shams Univ. 153 pp.

Goldschmidt, E.E.; Goren, R. and Monselise, S.P. 1968. The IAA oxidase system of citrus roots. Planta, 72: 213-222.

Gomez, K.A. and Gomez, A.A. 1984. Statistical Procedures for Agricultural Research, $2^{\text {nd }}$ Ed. John Wiley and Sons Ltd., New York, 680 pp.

Heil, M. and R. M. Bostock 2002. Induced systemic resistance (ISR) against pathogens in the context of induced plant defenses. Annals of Botany, 89: 503512.

Hussien, M.M.H. 1999. Advanced studies on barely powdery disease in Egypt. Ph.D. Thesis. Fac. of Agric., Zagazig Univ142 pp.

Khalifa, M.M.A. 1997. Studies of root-rot and wilt diseases of sesame plants. M.Sc. Thesis, Fac. Agric., Moshtohor, Zagazig Univ., Benha Branch,158 pp.

Khalifa, M.M.A. 2003. Pathological studies on charcoal rot disease of sesame. Ph.D. Thesis, Fac. Agric., Moshtohor, Zagazig Univ., Benha Branch, 295 pp.

Khalifa, M.M.A.; Abd-El-Megid, M.S. and Draz, E.E.I. 2007. Applying some chemical effectors for inducing systemic resistance against charcoal rot disease in Egypt. Egypt. J. Appl. Sci., 22 (10B): 431-446.

Kuc, J. 1982. Induced immunity to plant disease. Bio Science, 32: 832-854.

Egypt. J. Phytopathol., Vol. 39, No. 1 (2011) 
Kutchan, T.M. 1995. Alkaloid biosynthesis: The basis for metabolic engineering of medicinal plants. Plant Cell , 7:1059-1070.

Lawton, K.; S. Uknes, S.; Friedrich, L.; Gaffney, T.; Alexander, D.; Goodman, R.; Metraux, J.P.; Kessmann, H.; Ahl Goy, P.; Gut Rella, M.; Ward, E and Ryals, J. 1993. The Molecular Biology of Systemic Acquired Resistance. In: Fritig B., Legrand M. (eds) Mechanisms of Plant Defense Responses. Developments in Plant Pathology, vol 2. Springer, Dordrecht.

Mahmoud, E.Y.; Shokry S.Y.M. and Hussin, Z.N. 2006. Induction of resistance in peanut plants against root rot diseases under greenhouse conditions by some chemical inducers. J. Agric. Sci. Mansoura Univ., 31(6): 3511-3524.

Mahmoud, E.Y.; Ali, A.A.; Mansour, A.S. and Gomaa, A.M. 2009. Induction of resistance against peanut pod rots diseases and aflatoxin contaminations by some heavy metals and study their impact on the crop. J. Agric. Sci. Mansoura Univ.

Matta, A. and Dimond, A. E. 1963. Symptoms of Fusarium wilt in relation to quantity of fungus and enzyme activity in tomato stems. Phytopathology, 53: 547-587.

Mazen, M.M. 2004. Resistance induction against diseases of faba bean crop. PhD. Thesis, Fac. Agric., Suez Canal Univ.

Métraux J.P. 2001. Systemic acquired resistance and salicylic acid: Current State of Knowledge. European J. of Plant Path.107:13-18.

Métraux J.P. 1991. Induction of systemic resistance in cucumber in response to 2,6dichloro- isonicotinic acid and pathogens, [ in Adv. In Molecular Genetics of plant Microbe Interaction, Vol. 1, Hennecke, H. and Verma D., Kluwer Acad. Pub., Dordrechi, 432].

Moore, S. and Stein, W.H. 1954. A modified ninhydrin reagent for photometric determination of amino acids and related compounds. J. Biol. Chem., 211: 907-913.

Morsy, K.M.M. 2005. Induced resistance against damping-off root rot and wilt diseases of lentil. Egypt. J. Phytopathol., 33 (2): 53-63.

Oostendrop, M.; Kunz, W.; Dietricch, B. and Staub, T. 2001. Induced disease resistance in plants by chemicals. Eur. J. Plant Pathol. 107: 19-28.

Prakash, M.; Jagadeeswaran, G.; Murugan, S. and Ganessan, J. 1995. Effect of seed treatment on germination and seedling attributes in sesame (Sesamum indicum L.). Sesame and Safflower Newsletter, 10: 55-58.

Rao, G.K.; Satyanarayana, E. and Balasubramanyan, K. 1992. Comparative study of chlorophyll and sugar contents in resistant and susceptible cultivars of sorghum to charcoal rot. Madras. J. Agric. 79: 193-197.

Rao, M. V.; G. Paliath; Ormod, D.P.; Murr, D.P. and Watkins, C.B. 1997. Influence of salicylic acid on $\mathrm{H}_{2} \mathrm{O}_{2}$ production, oxidative stress, and $\mathrm{H}_{2} \mathrm{O}_{2}$-metabolizing enzymes. Plant Physiol., 115: 137-149.

Reuveni, R.; Shimoni, M.; Karchi, Z. and Kuc, J. 1992. Peroxidase activity as a biochemical marker for resistance of muskmelon (Cucumis melon) to Pseudoperonospora cubensis. Phytopathology, 82: 749-753. 
Sallam, M.E.A. 1997. Study on Leaf Rust of Wheat in Egypt. PhD. Thesis. Fac. of Agric., Zagazig Univ.119 pp.

Sauerborn, J.; Bschmann, H.; Ghiasvand, G.K. and Kogel, K.H. 2001. Benzothiadiazole activaties resistance in sunflower (Helianthus annus L.) to the root parasitic weed Orobanche cumana. Pyhtopathology, 91:59-64.

Shalaby, S.I.M. 1997. Induction of systemic resistance in sesame plants for controlling Fusarium wilt disease. Al-Azhar J. Agric. Res., 25: 17-29.

Shalaby, S.I.M. and Saeed, M.N.A. 2000. Biochemical defense mechanisms associated with the systemic induced resistance in sesame plants against Fusarium wilt disease. Zagazig J. Agric. Res. 27(1): 105-113.

Snell, F.D. and Snell, C.I. 1953. Colorimetric Methods. Vol. III. D. Van Nostrand Co. Inc., Torento, N. Y., London, 606 pp.

Thomas, W. and Dutcher, R.A. 1924. The colorimetric determination of carbohydrates in plants by the picric acid reduction method. I. The estimation of reducing sugars and sucrose. J. Amer. Chem. Soc., 46: 1662-1669.

Vernooij, B.; Friedrich, L.; Morse, A.; Reist, R.; Kolditz-Jawhar, R.; Ward, E.; Uknes, S.; Kessmann, H. and Ryals, J. 1994. Salicylic acid is not the translocated signal responsible for inducing systemic acquired resistance but is required in signal transduction. Plant Cell, 6: 959-965.

Walters, D.; Newton, A. and Lyon, G. 2007. Induced Resistance for Plant Defence. Blackwell Publishing Editorial Offices, 269 pp.

Youssef, Y.A. and Youssef, K.A. 1971. Studies of Fusarium wilt of cotton. VDifferences in contents of amino acids and sugars of seedlings of susceptible and resistant cotton varieties raised in Fusarium inoculated or uninoculated soil. U.A.R. J. Phytopathology, 3: 33-48.

Yu, Y.B. and Yang, S.F. 1979. Auxin induced ethylene production and its inhibition by amino ethoxy vinyl glycine and cobalt ion. Plant Physiol., 64: 1074-1076.

Zahra, A.M. 1990. Studies on wilt disease of sesame (Sesamum indicum L.) in upper Egypt. Ph.D. Thesis, Fac. Agric., Assuit Univ.

Zaky, W.H.; El-Sherbieny, S.N. and Mosa, A.A. 2002. Induced resistance of spearmint plant against rust disease caused by Puccinia menthae. Ann. Agric. Sci., Ain Shams Univ., Cairo (Egypt), 47(1): 417-429.

Ziedan, E.H.E. 1993. Studies on Fusarium wilt disease of sesame in ARE. M. Sc. Thesis, Fac. of Agric., Ain-Shams Univ.

Corresponding author: Khalifa, M.M.A.

E-mail: drmmakhalifa2014@gmail.com 


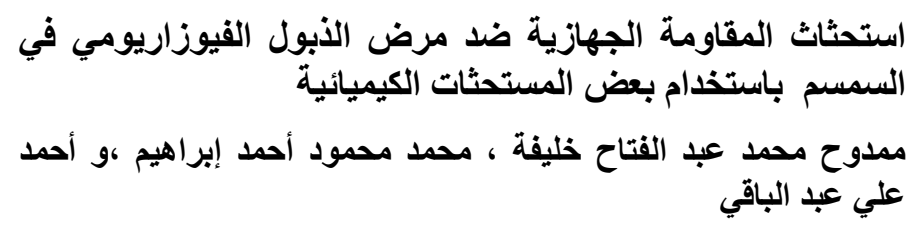

معهد بحوث أمراض النباتات ، مركز البحوث الزراعية ، الجيزة ، مصر.

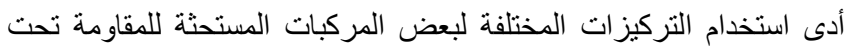

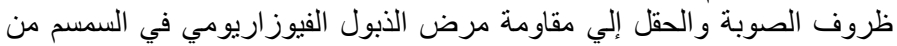

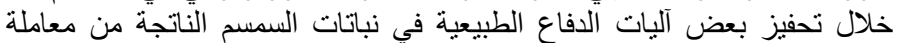

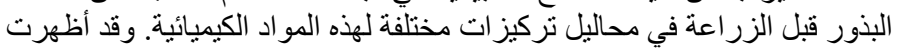

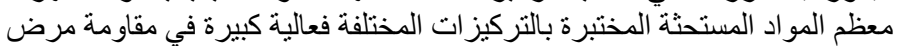

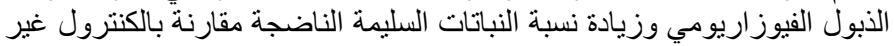

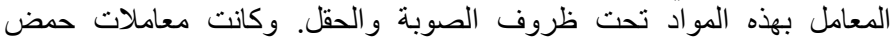

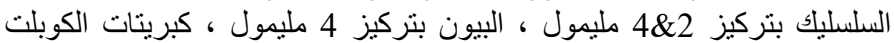

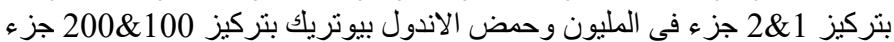

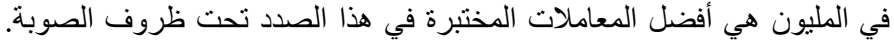

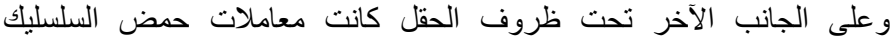
بتركيز 2\& مليمول ، البيون بتركيز 4 مليمول ، كبريتات الكوبلت بتربل بتركيز 1 و و 2

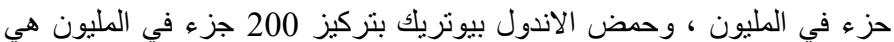

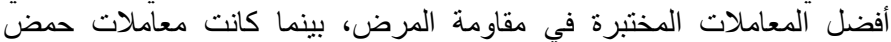

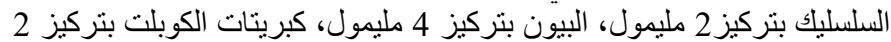

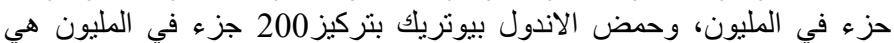

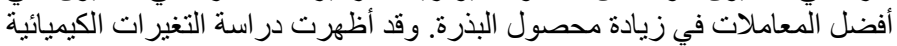

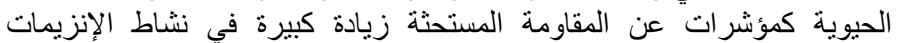

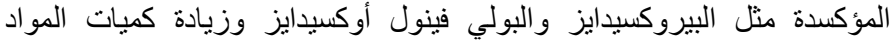

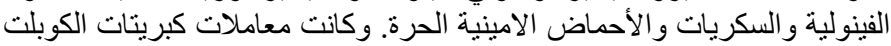

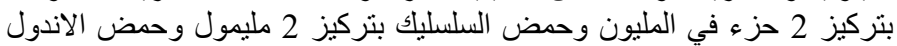

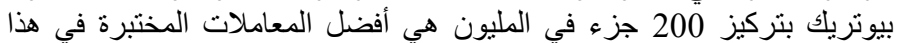
المجال مقارنة بالكنترول غير المعامل. فئل 